\title{
Determinants and Characteristics of Voluntary Internet Disclosures in GCC Countries
}

Ehab K. A. Mohamed. German University in Cairo. Egypt. ehab.kamel@ guc.edu.eg

Mohamed A. K. Basuony. American University in Cairo \& Ain Shams University. Egypt.

mohamed.basuony@aucegypt.edu

\begin{abstract}
The purpose of this paper is to examine the determinants and characteristics of voluntary Internet disclosures by listed companies in three Gulf Cooperation Council countries. This paper uses archival data from 192 listed companies in Qatar Stock Exchange, Muscat Securities Market, and Bahrain Bourse. Binary Logistic Regression analysis is used to examine the determinants of Internet financial reporting. Kruskal-Wallis test is used to examine the differences in disclosure characteristics among the three countries. The results reveal that firm size is the major influencing factor that impacts Internet financial reporting in the GCC. A number of disclosure characteristics differ significantly between the three countries. The paper provides insights into corporate Internet disclosure in the GCC that will benefit all stakeholders with an interest in corporate reporting in this important region of the world. The results are consistent with previous literature that corporate size is a major determinant of Internet financial reporting.
\end{abstract}

Keywords: Internet, financial reporting, disclosure, Qatar, Oman, Bahrain, GCC.

\section{INTRODUCTION}

This paper investigates and reports on the extent, nature and determinants of Internet financial reporting (IFR) among companies listed on three stock exchanges in three Gulf Corporation Council (GCC) Countries; namely Qatar, Oman and Bahrain. While IFR is fast becoming the norm in most western 
countries, there is little empirical evidence of the phenomenon in GCC countries. Until recently, hard copies (paper) have been the primary means for communicating financial information to shareholders and other interested corporate stakeholders. Technological advances have made the Internet a useful, timely and cost-effective tool for the communication of this information to stakeholders. The Internet has the potential to revolutionize financial reporting. Companies can include the traditional annual reports together with additional financial and non-financial information in multiple formats (Jones and Xiao, 2004).

Questions persist as to whether corporate organizations in the GCC are availing themselves of the opportunity provided by the Internet to communicate financial information to their stakeholders. While the use of the Internet for the communication of financial information raises a variety of challenging issues, there is little doubt about its benefits. Given the increasing importance of IFR and the lack of empirical study on IFR practices in the Middle East, this paper provides an important contribution to filling the gap in our knowledge of this subject. This is of particular importance in a time when there is so much interest in investment opportunities in the GCC countries where rapid economic growth is fuelled by booming oil revenues.

Evidence of IFR practices in various countries have been presented by a number of academic and professional studies - see, for example, Craven and Marston (1999), Jones and Xiao (2004) and Gowthorpe (2004) - UK, Deller et al. (1999) - US, UK and Germany, Gowthorpe and Amat (1999) - Spain, Hedlin (1999) - Sweden, Lymer (1999) and Bonson and Escobar (2002) - Europe, Pirchegger and Wagenhofer (1999) - Austria and Germany, Marston and Polei (2004) - Germany, Trites (1999) - US and Canada, Ettredge et al. (2001) - US, Debreceny et al. (2002) and Lymer and Debreceny (2003) - International Comparison, Oyelere et al. (2003), Fisher et al. (2004) and Laswad et al. (2005) New Zealand, Marston (2003) - Japan, Xiao et al. (2004) - China, Smith and Peppard (2005) - Ireland, Khadaroo (2005) - Malaysia, and Chan and Wickramasinghe (2006) - Australia, Ismail and Sobhy (2009) - Egypt, Salawu (2009) - Nigeria, Lai et al. (2010) - Taiwan, Mohamed (2010) - GCC, del Carmen Briano Turrent and Ariza, (2012) - Spain and Mexico, Oyelere and Kuruppu (2012) - UAE. A summary of main issues investigated and key findings 
of some of these studies are presented in Appendix A. They indicate the growing use of the Internet for the corporate dissemination of information, including providing annual reports on the Internet, and that the extent and sophistication of IFR practices varies across countries.

The paper has threefold objective, first it provides an insight into the internet corporate disclosure characteristics in GCC countries; second it examines the differences in those disclosure characteristics among the three countries studied; third it examines the determinants of internet financial disclosure in the three GCC countries. The rest of this paper is structured as follows. A review of relevant literature and hypotheses development is provided in the next section. The research methodology is discussed in Section three. Section four provides analyses and discussions on the extent, nature and determinants of IFR by companies listed in the three stock exchanges. Summary and conclusions are presented in the final section.

\section{LITERATURE REVIEW}

\subsection{Background}

The Internet provides a useful communication tool for corporate organizations. One of the main benefits of IFR is the potential for large savings in the cost of production and distribution of financial information. The Internet allows companies to reach a much wider range of stakeholders at a relatively lower cost. The use of IFR also leads to a reduction in incidental requests from nonshareholder financial statement users (Allam and Lymer, 2002; SEC, 2002, 2003a,b; Khadaroo, 2005). The literature also documents a number of other benefits that may accrue from IFR (Baker and Wallage, 2000; Ettredge et al., 2001; Debreceny et al., 2002; Wagenhofer, 2003; Jones and Xiao, 2004; Boritz and No, 2005). These include more equitable information dissemination among stakeholders as a result of the improved accessibility of the information. With IFR users can choose to access information that meets their specific needs as the Internet allows non-sequential access to information through the use of hyperlinks, interactivity and search facilities. IFR also presents companies with the opportunity to provide more information than is available in annual reports. The Internet provides an opportunity for going beyond what is available in hard 
copy corporate financial statements to communicate additional financial information to users, possibly in real-time and on an interactive basis (McCafferty, 1995; Louwers et al., 1996; Green and Spaul, 1997; Trites and Sheehy, 1997; Trites, 1999; FASB, 2000; Ettredge et al., 2002; Wickramasinghe, 2006). IFR provides corporate organizations with a real opportunity to extend financial disclosure beyond the reproduction of a hard copy annual report and improve on the timeliness, scope, and interactivity of financial reporting, with multimedia, such as sound, animation and video, being used to potentially increase the understanding of information (Louwers et al., 1996; Ravlic, 2000; Wickramasinghe and Lichtenstein, 2006). These developments have a great potential impact on users (Wallman, 1997; Green and Spaul, 1997; Gowthorpe and Flynn, 2001).

A number of IFR-related issues and challenges have been noted in the literature. It is possible that the dividing line between current financial information used by management and historical audited financial information made available to public users of financial information could be erased by online, real-time reporting (Green and Spaul, 1997; Hodge, 2001; Oyelere et al., 2003), with auditors being possibly required to provide opinion on such hither to internal financial information (Trites and Sheehy, 1997; Lymer and Debreceny, 2003; Khadaroo, 2005). If IFR is installed as the only mode for communicating financial information it is likely that access to such information will be restricted to only those who possess costly computer equipment and skills. Hence, to ensure equitable access to financial information it will be necessary to ensure that the information being reported through corporate websites is also provided through other media of financial information disclosure (McCafferty, 1995). This could be seen as unnecessary duplication and may result in even greater costs in the Middle East where financial information is commonly disseminated in both English and Arabic.

Additional issues and challenges for IFR include possible errors in the extraction or re-keying process, which may affect the reliability and integrity of the financial information; Generally Accepted Accounting Practice (GAAP) implications of IFR; the use of the corporate websites for many diverse purposes, which may make the location of financial information difficult; and the 
acceptability of Internet financial reports as alternatives to hard copy annual reports among users of corporate financial information (Laswad et al., 2000).

By far the greatest challenge faced in the IFR environment is that of ensuring the security and integrity of the financial information published on corporate websites. Apart from possible errors in the publishing process, materials published on the web are susceptible to all manners of security risks. Financial information could, post-publication, be knowingly or unknowingly altered by parties both external and internal to the organization. There is a real risk that critical decisions could be made by users of financial information based on inaccurate financial information gleaned from corporate websites. The extent to which these issues are dealt with is likely to determine the long-term usefulness of the Internet as a medium of corporate financial information dissemination.

\subsection{Institutional Framework}

\section{Qatar Exchange}

Qatar has the fastest growing economy in the GCC region and according to the International Monetary Fund (2012) it has the highest GDP per capita in the world. Qatar has shown a rapid economic growth and it is expected that the growth will continue especially after the decision by FIFA to award the 2022 World Cup to Qatar. To support the economic growth and Qatar's integration into the global economy, the authorities in Qatar launched the Qatar Financial Centre (QFC) in 2005. The aim of this initiative was to attract top firms in finance, energy, tourism, transportation, health, and education.

Qatar has established its stock exchange in 1995 under the name of Doha Securities Market (DSM) and official operation started in 1997. In June 2009 the exchange was turned into a shareholding company under the new name, Qatar Exchange $(\mathrm{QE})$ as a result of Qatar Holding, the strategic and direct investment arm of Qatar Investment Authority (QIA), and NYSE Euronext, the world's leading exchange group, signed an agreement to form a major strategic partnership to establish the Exchange as a world-class market. Since its inauguration in 1997 the exchange has grown to become one of the leading stock markets in the GCC region. The Qatar Exchange aims to support Qatar's economy by providing a venue for capital raising for companies and giving investors a 
platform through which they can trade in a transparent and efficient manner. The Qatar Exchange also provides the public with access to market information and ensures adequate disclosure.

There currently 42 companies listed on the Qatar Exchange. Companies listed on the QE are governed by both company and securities market laws. The four main laws that are related to financial reporting by listed companies are Company Law No. 11 of 1981, Doha Securities Market Law No. 14 of 1995, Commercial Companies Law No. (5) of 2002, and Qatar Central Bank Law No. 33 of 2006. The laws require the board of directors to prepare annual financial statements with explanations in respect of the previous fiscal year, a report about the activity of the company, and the plan for the coming year. The financial statements must be audited and finalised within a maximum of three months after the expiry of the company's fiscal year for submission to the general assembly of the shareholders which must be held within a maximum of four months from the expiry of the company's fiscal year. However, there is no guidance on internet financial reporting.

\section{Muscat Securities Market - Oman}

The government of Oman realized sometime ago that in order to keep pace with international developments and enable the vision of a solid economy that will be recognised internationally, it was necessary to have a strong financial sector based on well-established financial companies. This would also facilitate a suitable environment for successful companies and projects that could add value to the national economy. To realise these objectives, it was decided to set up a Stock Exchange. The Exchange, called Muscat Securities Market (MSM), was set up by Royal Decree 53/88, issued on 21 June 1988. The decree set the legal framework for the establishment of the Muscat Securities Market as an independent organization to regulate and control the Omani securities market and to participate with other organizations in setting up the infrastructure of the Sultanate's financial sector. After ten years of continuous growth of both the national economy and the Market, and in order to cope with new developments in the local and international financial sector, particularly in the securities industry, it was decided that there was a need for better control and regulation of market activities so as to provide better protection to investors. To achieve this, it was decided to split the functions of regulation and market activities, both of which were until then functions of the 
MSM. Existing laws and regulations were amended to bring the market closer to international standards of practice, where the norm is to have an independent regulator with regulatory authority over the Exchange and market participants.

The MSM was restructured by the issue of two Royal Decrees 80/98 and 82/98. Royal Decree 80/98 of 9 November 1998 provided for the establishment of two separate entities:

- a regulator, the Capital Market Authority (CMA), which will be a governmental authority responsible for organizing and overseeing the issue and trading of securities in the Sultanate; and

- an exchange, the Muscat Securities Market (MSM), where all listed securities shall be traded. The exchange shall also be a governmental entity, financially and administratively independent from the authority but subject to its supervision. The board of directors shall be elected from among members of public (governmental commercially oriented) corporations, listed companies, intermediaries, and the Central Bank of Oman.

Royal Decree 82/98 of 25 November 1998 established the Muscat Depository and Securities Registration Company, a closed joint stock company, as the sole provider of the services of registration and transfer of ownership of securities and safe keeping of ownership documents (depository) in the Sultanate. This company is linked through an electronic system to the MSM for easy data transfer.

The government of Oman aimed to institute a well-established securities industry in the country to help develop and sustain investors' confidence in the stock market. As a continuing process in the development of the securities market, the CMA has developed its website to make information and financial data related to the performance of the Muscat Securities Market and all listed companies available to and directly accessible by investors. This is aimed not only at ensuring transparency of activities, which is considered one of the main principles of a well organized market, but also at supporting the market by encouraging investors to make the right investment decisions. The MSM currently lists 126 companies. 


\section{Bahrain Bourse}

Over the years, the Bahrain Bourse (BB) has grown to become one of the leading emerging stock markets in the Middle East. The Exchange started off with 29 listed companies in 1989 and increased to 41 companies in 2000 (including the first non-GCC company to list in the region) and 48 companies in 2013. The equity market capitalization rose from BD1.04 billion (US\$2.7 billion) in 1989 to BD2.5 billion (US\$6.6 billion) in 2000, an increase of approximately 20 percent per annum; the current total capitalization in 2014 is approximately BD20 billion (US $\$ 52$ billion).

In 1997, the BSE's board of directors adopted a strategy to develop and expand operations at the Exchange in order to increase its competitiveness. The strategy focused on the strengthening of the legal infrastructure, adoption of automated technical systems, staff training and marketing and promotion. The market was opened up to foreign investors in 1999. Foreign investors were allowed to own up to 49 percent of investments (previously $24 \%$ ).

In 1999, an automated trading system was installed. This was followed by installation of an automated Clearing, Settlement, Depository and Registration System. The Exchange implemented International Organization of Securities Commissions (IOSCO) international disclosure standards, as well as other standards used in international stock markets, resulting in one of the most farreaching disclosure standards adopted in the region.

The BSE aims to operate in a completely transparent environment, with timely dissemination of information. Companies listed on the Exchange are required to publish their financial statements within three months of the end of their annual financial year to improve the timeliness of information disclosure. The Exchange has, as one of its stated aims, the harnessing of the capabilities of the Internet to bring investors in closer touch with its business. It views the Internet as a veritable tool for communication and business operations. By extension, one would expect companies listed on the Exchange to embrace the technology and use it for a variety of purposes, including the communication of corporate governance information to their stakeholder groups. 


\subsection{Hypotheses Development}

The Gulf Cooperation Council (GCC) countries have witnessed a period of high economic growth in the last two decades. New investment opportunities have been created the prosperity from the exploitation of oil resources that resulted in increased savings. The huge flow of funds into the banking system and corporations has led to increased demands from lenders and investors to raise standards of corporate governance (Hussain and Mallin, 2002; Hussain et al., 2002; Joshi and Wakil, 2004). According to the World Bank the estimated GDP of GCC countries in 2011 was $\$ 1,450$ Billion.

\begin{tabular}{lrrrr}
\hline Country & Population & Internet Users in & Internet Users in & $\begin{array}{r}\text { \% of } \\
\text { Population }\end{array}$ \\
\hline Bahrain & $1,248,348$ & 40,000 & 961,228 & $77.0 \%$ \\
Oman & $3,090,150$ & 90,000 & $2,101,302$ & $68.8 \%$ \\
Qatar & $1,951,591$ & 30,000 & $1,682,271$ & $86.2 \%$ \\
\hline Total GCC & $\mathbf{6 , 2 9 0 , 0 8 9}$ & $\mathbf{1 6 0 , 0 0 0}$ & $\mathbf{4 , 7 4 5 , 4 0 1}$ & $\mathbf{7 5 . 4 \%}$ \\
\hline
\end{tabular}

Source: Statistic Brain www.statisticbrain.com

Table 1. Population and Internet Users

Internet usage is widely spread in GCC countries. Table 1 reveals the significant increase in the number of Internet users in GCC countries during the last decade, however very little, if any, evidence exists on the extent and nature of IFR practices in the GCC countries. It is predicted that IFR is likely to overtake the hard-copy print form of financial information disclosure in the near future. It is therefore surprising that evidence on the variety of issues associated with this form of financial disclosure is currently not being publicly discussed. Such evidence will depend on the outcome of thorough, in-depth investigation and analysis, such as is being preliminarily undertaken in the current study. Therefore, considering the importance of IFR in disseminating financial information and the little research of these practices in emerging economies, the objective of this paper is to study the extent, practices and determinants of IFR in Qatar, Oman and Bahrain. While those three countries share a number of characteristics due to being in the same region and sharing similar cultures, they are at different stages of development, or with different business environments that may affect the attributes of Internet financial disclosure. This argument leads to the first hypothesis: 
$H_{1}$. There is a significant difference in the characteristics of corporate Internet disclosure among the three GCC countries.

Recent studies have provided evidence on the factors motivating the IFR behaviour of companies around the world. Given the voluntary nature of IFR, these studies sought to establish the reason why companies engage in IFR and the extent of such engagement. The majority of these studies have found corporate size to be a major factor, with IFR likely to provide greater economies of scale cost savings for larger firms (Ashbaugh et al., 1999; Craven and Marston, 1999; Pirchegger and Wagenhofer, 1999; Debreceny et al., 2002; Ettredge et al., 2002; Oyelere et al., 2003; Fisher et al., 2004; Chan and Wickramasinghe, 2006; Trabelsi, 2007). Evidence on other variables examined is largely inconclusive.

\section{Firm Size:}

Several studies examine the relationship between firm size and voluntary disclosure (Malone et al., 1993; Ahmed and Nicholls, 1994; Raffournier, 1995; Haniffa and Cooke, 2005; Almilia and Surabaya 2009; Aly et al. 2009). It is argued that stock market pressure forces large corporations to disclose more information on their websites to assist them in increasing their outside capital to enhance their performance. Hence, large corporations are more able to access financial markets through disclosing more information online (Bonson and Escobar, 2002). Large corporations can disclose information on the Internet for lower costs as they have the resources to do so. Agency theory implies that large firms exhibit higher agency costs due to the information asymmetry between market participants (Jensen and Meckling, 1976). To reduce these agency costs, larger firms disclose a large flow of corporate information. While, according to the political cost hypothesis, large firms attract more financial analysts putting firms under higher pressure because they are more publicly visible (Boubaker $e t$ $a l ., 2012$ ). Due to the industrial competition between companies, smaller firms tend to hide their important information (Marston 2003, Almilia and Surabaya 2009). Moreover, large companies always have a larger number of products and their distribution networks are more complex than smaller firms. Thus, information disclosure is required more in large companies (Marston 2003; Aly et al. 2009).

Empirical findings suggest a significant relationship between the firm size and online disclosure (Hossain et al., 1995; Ashbaugh et al., 1999; Craven and 
Marston, 1999; Pirchegger and Wagenhofer, 1999; Brennan and Hourigan, 1998; Bonson and Escobar, 2002; Debreceny et al., 2002; Ettredge et al., 2002; Larrán and Giner, 2002; Oyelere et al., 2003; Marston and Polei, 2004; Xiao et al., 2004; García-Borbolla et al., 2005; Bollen et al., 2006; Ezat and El-Masry, 2008). This prompts the second research hypothesis:

$\mathrm{H}_{2}$. There is a significant relationship between firm size and IFR

\section{Profitability:}

It is suggested that firm profitability can be regarded as an indicator to good management, as management tends to disclose more information when the rate of return is high. Hence, profitable companies have extra financial resources to disseminate financial information voluntary and have more incentives to disclose to both the stakeholders and public that they are more profitable than their counterparts in the same industry. This can be justified by the agency theory, where managers of the highly profitable companies disseminate more information on their companies' website to achieve personal advantages such as the marinating their positions and justifying compensations (Singhvi and Desai, 1971; Wallace et al., 1994; Haniffa and Cooke, 2005). Furthermore, signaling theory suggests that profitable companies have an incentive to disclose more information, to signal the firm's profitability to investors and to raise capital at the lowest price (Oyeler et al., 2003; Marston and Polei, 2004). However, there are mixed results with some studies revealing significant relationship between firm profitability and Internet financial disclosure (Ashbaugh et al., 1999; Ismail, 2002; Debreceny and Rahman, 2005), while other studies find no significant relationship between profitability and online financial disclosure (Larrán and Giner, 2002; Oyelere et al., 2003; Marston and Polei, 2004; Xiao et al., 2004; Momany and Al-Shorman, 2006; Ezat and El-Masry, 2008). Thus, the third research hypothesis is:

$H_{3}$. There is a significant relationship between profitability and IFR

Leverage:

Based on the agency theory, the agency costs of loan capital depend on the nature of claims held by outsiders. It suggests that the costs are higher for firms with 
proportionally more debt in the capital structure (Leftwich, 1981). Voluntary disclosure can reduce the agency costs by facilitating debt supplier's assessment of a firm's ability to meet its debts (Jensen and Meckling, 1976). Thus, it is suggested that firms that are highly leveraged are more inclined to try and satisfy debt suppliers by disseminating reliable information on the website to make these creditors more confident about the ability of the companies to pay their debts. Though this dissemination results in extra disclosure costs, providing reliable information to debt suppliers reduces agency costs. Likewise, shareholders demand more information to assess the firm's financial ability (Ismail, 2002; Larrán and Giner, 2002; Oyelere et al., 2003; Xiao et al., 2004).

Nonetheless, the literature offers inconclusive evidence on the relationship between leverage and Internet financial disclosure. Some studies show a significant positive relationship (Mitchell et al. 1995; Hossain et al. 1995; Xiao et al., 2004), other studies show a significant negative relationship (Meek et al., 1995), while others show an insignificant relationship (Brennanand and Hourigan, 2000; Debreceny et al., 2002; Larrán and Giner, 2002; Oyelere et al., 2003; Bollen et al., 2006; Ezat and El-Masry, 2008). Hence, the fourth hypothesis is:

$H_{4}$. There is a significant relationship between leverage and IFR.

Industry Type:

According to the signalling theory, companies within the same industry tend to adopt the same level of disclosure. When a company within an industry tends not to follow the same disclosure practices, including Internet disclosures, as others in the same industry, then it may be interpreted as a signal that the company is hiding bad news (Craven and Marston, 1999). The difference in disclosure practices between different industries may be due to different industries having different proprietary costs of disclosure and some may be more technologically advanced than others (Ismail, 2002). Several studies examine the relationship between the type of business activity and Internet financial disclosure. The findings are mixed with some studies revealing a significant relationship between Internet financial disclosure and industry type (Ashbaugh et al., 1999; Craven and Marston, 1999; Brennan and Hourigan, 1998; Bonson and Escobar, 2002; Garci'a-Borbolla et al., 2005; Ismail, 2002; Oyelere et al., 2003, Ezat and ElMasry, 2008, Aly et al., 2009). However, others show insignificant relationship 
(Debreceny and Rahman, 2005; Larrán and Giner, 2002; Trabelsi and Labelle, 2006). This leads us to the fifth research hypothesis:

$H_{5}$. There is a significant relationship between industry type and IFR Audit Type:

It is suggested that audit quality is an important factor in improving firms' overall reporting practices. International audit firms are more likely to facilitate the diffusion of innovative practices, such as the Internet financial reporting (Hail, 2002; Xiao et al., 2004). Agency theory suggests that auditing helps mitigate agency costs due to the interest conflicts between manager and shareholders. Big auditors are likely to be independent and could constrain managers to maintain more stringent disclosure standards (DeAngelo, 1981). Large international audit firms are likely to demand high-quality disclosure. This could be explained by the signaling theory because managers that hire large auditing firms signal to the market that they are willing to provide quality disclosures (Healy and Palepu, 2001).

The findings of some prior studies reveal a positive relationship between audit type and Internet financial disclosure (Ahmed and Nicholls, 1994; Raffournier, 1995; Xiao et al., 2004; Boubaker et al., 2012). Though, other studies did not find any significant relationship between audit type and disclosure (Wallace et al., 1994; Hossain et al., 1995; Abd El Salam, 1999, Aly et al., 2009). Therefore, the sixth research hypothesis is:

$H_{6}$. There is a significant relationship between audit type and IFR

\section{METHODOLOGY}

The aim of this study is to investigate and document the extent and nature of IFR practices among firms listed on the GCC countries. The research methodology employed to accomplish this aim is presented in this section. The population of the study consists of firms that are publicly listed in the stock exchanges of Qatar, Oman and Bahrain. Internet disclosure data are collected during the period from January to March 2013. Financial data for the independent variables are taken from the anual reports for 2011 as it is the most recent year for which company annual reports are available for the entire sample at the time of undertaking this 
research. Table 2 shows the population and samples selected for each of stock exchanges:

\begin{tabular}{ccccc}
\hline & Qatar & Oman & Bahrain & Total \\
\hline All listed companies & 42 & 126 & 48 & 216 \\
Unavailable data & $(3)$ & $(13)$ & $(1)$ & $(17)$ \\
Cross listing & - & - & $(2)$ & $(2)$ \\
Suspended firms & - & - & $(5)$ & $(5)$ \\
\hline Total & $\mathbf{3 9}$ & $\mathbf{1 1 3}$ & $\mathbf{4 0}$ & $\mathbf{1 9 2}$
\end{tabular}

Source: www.qe.com.qa; www.msm.org.om; www.bahrainbourse.net

Table 2. Population and Samples per Stock Exchange

Finally, the sample of this study consists of 192 firms out of 216 after excluding 2 firms for cross listing, 5 firms for being suspended, and 17 firms with unavailable data. Moreover, these 192 firms consist of 39 firms from Qatar, 113 firms from Oman and 40 firms from Bahrain. Table 3 shows the sample selected for each of stock exchange in each country.

\begin{tabular}{lrr}
\hline Country & Number of Companies & \% \\
\hline Qatar & 39 & $20 \%$ \\
Oman & 113 & $59 \%$ \\
Bahrain & 40 & $21 \%$ \\
\hline Total & $\mathbf{1 9 2}$ & $\mathbf{1 0 0 . 0 \%}$ \\
\hline
\end{tabular}

Table 3. Sample by Country

Data regarding whether these companies have website or not were obtained via searching the names of these companies in Internet search engines. Where corporate sites are available, we moved to the next stage of the data collection process by investigating the type of information provided at these sites. Four categories of information - company history/background, products/services, financial and other information - were of interest to us at this stage. The next stage of the data collection process involved querying the extent and nature of financial information provided on the corporate websites. Of interest are the type 
of financial information - that is, whether full financial statements and/or financial highlights; the format of presentation, that is whether PDF, HTML, other formats or a combination of these; and the volume of financial information presented. This data collection approach is similar to the one used by Craven and Marston (1999), Deller et al. (1999), Oyelere et al. (2003), and Laswadet al. (2005).

The objective of this paper is to examine Internet financial reporting practices and its determinants in firms listed in Qatar stock exchange (QE), Muscat securities market (MSM) and Bahrain Bourse (BB). Table 4 shows the definition and measurement of these variables.

\begin{tabular}{|c|c|c|}
\hline Symbol & $\begin{array}{l}\text { Variable } \\
\text { Definition } \\
\end{array}$ & Measurement \\
\hline \multicolumn{3}{|c|}{ Dependent Variables } \\
\hline IFR & $\begin{array}{l}\text { Internet } \\
\text { Financial } \\
\text { Reporting } \\
\end{array}$ & $\begin{array}{l}\text { IFR }=1 \text { when companies provide annual financial reports on their websites; IFR } \\
=0 \text { when companies do not provide annual financial reports on their websites } \\
\text { (Also, non-existence of a company website results in IFR =0) }\end{array}$ \\
\hline \multicolumn{3}{|c|}{ Independent Variables (Determinants) } \\
\hline FrmSize & Firm Size & Natural log of total assets \\
\hline ROA & $\begin{array}{l}\text { Return on } \\
\text { Assets }\end{array}$ & Net Income / Total Assets \\
\hline Lvg & Leverage & Total equity/ Total Assets \\
\hline IndTyp & Industry Type & $\begin{array}{l}\text { Manufacturing }=1 ; \text { Non-financial Services }=2 ; \\
\text { financial Services }=3\end{array}$ \\
\hline AudTyp & Auditor Type & If 'Big 4' $=1$; otherwise $=0$ \\
\hline \multicolumn{3}{|c|}{ Control Variables } \\
\hline Market & Stock Market & $\mathrm{QE}=1 ; \mathrm{MSM}=2 ; \mathrm{BB}=3$ \\
\hline
\end{tabular}

Table 4. Definition and Measurement of Variables

\section{RESULTS AND DISCUSSION}

\subsection{Descriptive Analysis}


Table 5 illustrates the mean, standard error and standard deviation values for dependent and independent variables (Panel A) and Internet disclosure characteristics (Panel B).

\begin{tabular}{lrrr}
\hline \multicolumn{1}{c}{ Variable } & Mean & S.E. & S.D. \\
\hline Panel A & & & \\
IFR & 0.63 & .035 & .485 \\
ROA & 0.035 & .006 & .088 \\
Audit Type & 0.80 & .030 & .416 \\
Industry Type & 1.97 & .057 & .785 \\
Leverage & 0.540 & .044 & .612 \\
Firm Size & 20.253 & .167 & 2.310 \\
& & & \\
Panel B & & & .299 \\
English Website & & .022 & .491 \\
Arabic Website & 0.90 & .035 & .478 \\
Investor Relation & 0.40 & .034 & .261 \\
CG Report & 0.35 & .031 & .399 \\
Email Link & 0.25 & .019 & .299 \\
Multimedia & 0.93 & .029 & .326 \\
Company Information & 0.80 & .022 & .501 \\
Products \& Services Information & 0.90 & .023 \\
Forward Looking Information & 0.88 & .036 & .493 \\
Figures \& Graphs & 0.48 & .032 & .490 \\
General Financial Information & 0.27 & .036 &
\end{tabular}

Table 5. Descriptive Analysis

The 192 companies listed on the three stock exchanges in Qatar, Oman and Baharin are three industrial sectors. A distribution of the 192 companies among the different industrial sectors is presented in Table 6. As it can be seen from figure 1 , the sample is almost evenly distributed among the three sectors.

\begin{tabular}{lrrrrr}
\hline Country & Manufacturing & $\begin{array}{r}\text { Non-Financial } \\
\text { Services }\end{array}$ & $\begin{array}{r}\text { Financial } \\
\text { Services }\end{array}$ & Total & \% \\
\hline Qatar & 5 & 20 & 14 & 39 & $20 \%$ \\
Oman & 54 & 35 & 24 & 113 & $59 \%$ \\
Bahrain & 3 & 19 & 18 & 40 & $21 \%$ \\
\hline Total & $\mathbf{6 2}$ & $\mathbf{7 4}$ & $\mathbf{5 6}$ & $\mathbf{1 9 2}$ & \\
\hline $\boldsymbol{\%}$ & $\mathbf{3 2 . 2 9 \%}$ & $\mathbf{3 8 . 5 4 \%}$ & $\mathbf{2 9 . 1 7 \%}$ & & $\mathbf{1 0 0 . 0 \%}$ \\
\hline
\end{tabular}

Table 6. Sample Distribution 


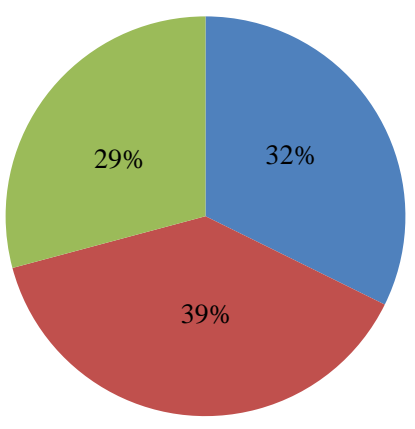

Manufacturing

- Non-Financial Services

Financial Services

Figure 1. Distribution by Industry Type

Table 7 shows that the majority of companies (79\%) operating in the GCC hire Big 4 audit firms. The highest percentage is in Qatar where 90\% of companies hire Big 4 audit firms, in Oman it is $75 \%$ and $78 \%$ in Bahrain as it can be seen in figure 2 .

\begin{tabular}{lrrr}
\hline Country & Big $\mathbf{4}$ & Non-Big 4 & Total \\
\hline Qatar & 35 & 4 & 39 \\
Oman & 85 & 28 & 113 \\
Bahrain & 31 & 9 & 40 \\
\hline Total & $\mathbf{1 5 1}$ & $\mathbf{4 1}$ & $\mathbf{1 9 2}$ \\
\hline \% & $\mathbf{7 8 . 6 5 \%}$ & $\mathbf{2 1 . 3 5 \%}$ & \\
\hline
\end{tabular}

Table 7. Auditor Type

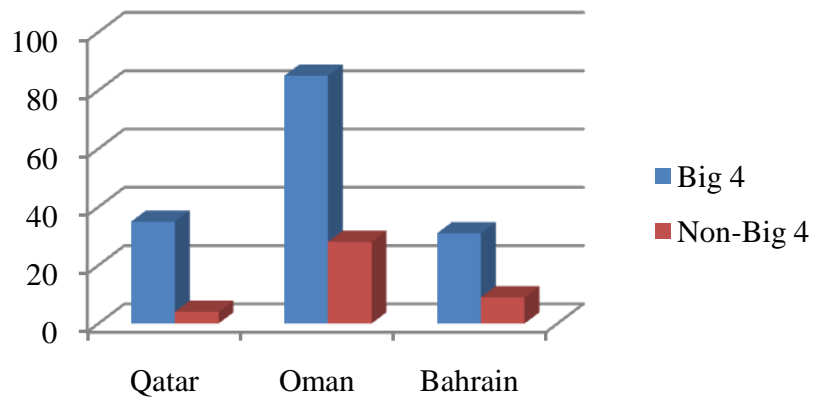

Figure 2. Auditor Type 
A classification of "websiters" and "non-websiters" by country is provided in Table 8 and 9. Overall, 173 companies (90\%) have English websites, while only 77 companies (40\%) have Arabic websites. All companies in Qatar (39) have English websites and 33 (85\%) have Arabic websites. Oman, 96 companies (85\%) have English website and 24 companies (21\%) have Arabic website. 95\% of Bahraini listed companies have English websites and 50\% have Arabic websites. Generally, the proportion of website ownership appears good when compared with developed western countries such as the US, the UK, Australia and New Zealand (Lymeret al., 1999; Oyelere et al., 2003; Chan and Wickramasinghe, 2006).

\begin{tabular}{lllllr}
\hline Country & \multicolumn{2}{l}{ With Website } & \multicolumn{2}{l}{ Without Website } & Total \\
\hline Qatar & 39 & $100 \%$ & 0 & $0 \%$ & 39 \\
Oman & 96 & $85 \%$ & 17 & $15 \%$ & 113 \\
Bahrain & 38 & $95 \%$ & 2 & $5 \%$ & 40 \\
\hline Total & $\mathbf{1 7 3}$ & $\mathbf{9 0 \%}$ & $\mathbf{1 9}$ & $\mathbf{1 0 \%}$ & $\mathbf{1 9 2}$ \\
\hline
\end{tabular}

Table 8. Listed Companies With or Without English Websites by Country

\begin{tabular}{lllllc}
\hline Country & \multicolumn{2}{l}{ With Website } & \multicolumn{2}{c}{ Without Website } & Total \\
\hline Qatar & 33 & $85 \%$ & 6 & $15 \%$ & 39 \\
Oman & 24 & $21 \%$ & 89 & $79 \%$ & 113 \\
Bahrain & 20 & $50 \%$ & 20 & $50 \%$ & 40 \\
\hline Total & $\mathbf{7 7}$ & $\mathbf{4 0 \%}$ & $\mathbf{1 1 5}$ & $\mathbf{6 0 \%}$ & $\mathbf{1 9 2}$ \\
\hline
\end{tabular}

Table 9. Listed Companies With or Without Arabic Websites by Country

Table 10 provides description of Internet disclosure attributes. Overall, most companies provide information on company (99\%), Email link (98\%), product and services (97\%). On the other hand, only $28 \%$ of companies disclose corporate governance information and $39 \%$ have a section for investor relations. While $89 \%$ of companies use multimedia on their websites, only $30 \%$ use figures and graphs. The number of companies that use their website for Internet financial reporting is 120 out of $173(69 \%)$ and $67 \%$ of the companies have the current annual report (2012) disclosed. A breakdown of the overall results is shown in table 11. 


\begin{tabular}{lccccc}
\hline \multicolumn{1}{c}{ Disclosure Attribute } & Yes & $\mathbf{\%}$ & No & \% & Total \\
\hline Investor Relation & 67 & $39 \%$ & 106 & $61 \%$ & $\mathbf{1 7 3}$ \\
CG Report & 48 & $28 \%$ & 125 & $72 \%$ & $\mathbf{1 7 3}$ \\
Email Link & 169 & $98 \%$ & 4 & $2 \%$ & $\mathbf{1 7 3}$ \\
Multimedia & 154 & $89 \%$ & 19 & $11 \%$ & $\mathbf{1 7 3}$ \\
Company Information & 171 & $99 \%$ & 2 & $1 \%$ & $\mathbf{1 7 3}$ \\
Products \& Services Information & 167 & $97 \%$ & 6 & $3 \%$ & $\mathbf{1 7 3}$ \\
Forward Looking Information & 92 & $53 \%$ & 81 & $47 \%$ & $\mathbf{1 7 3}$ \\
Figures \& Graphs & 52 & $30 \%$ & 121 & $70 \%$ & $\mathbf{1 7 3}$ \\
General Financial Information & 113 & $65 \%$ & 60 & $35 \%$ & $\mathbf{1 7 3}$ \\
IFR & 120 & $69 \%$ & 53 & $31 \%$ & $\mathbf{1 7 3}$ \\
Current Annual Report & 116 & $67 \%$ & 57 & $33 \%$ & $\mathbf{1 7 3}$ \\
\hline
\end{tabular}

Table 10. Overall Internet Disclosure Statistics

\begin{tabular}{lcc|cc|cc}
\hline \multirow{2}{*}{ Disclosure Attribute } & \multicolumn{2}{c|}{ Qatar } & \multicolumn{2}{c|}{ Oman } & \multicolumn{2}{c}{ Bahrain } \\
\cline { 2 - 7 } & No. & \%* & No. & \%** & No. & \%*** \\
\hline Investor Relation & 31 & $79.50 \%$ & 18 & $18.75 \%$ & 18 & $47.37 \%$ \\
CG Report & 25 & $64.10 \%$ & 8 & $8.33 \%$ & 15 & $39.47 \%$ \\
Email Link & 37 & $94.90 \%$ & 96 & $100 \%$ & 36 & $94.74 \%$ \\
Multimedia & 37 & $94.90 \%$ & 80 & $83.33 \%$ & 37 & $97.37 \%$ \\
Company Information & 38 & $97.40 \%$ & 96 & $100 \%$ & 37 & $97.37 \%$ \\
Products \& Services Information & 38 & $97.40 \%$ & 96 & $100 \%$ & 33 & $86.84 \%$ \\
Forward Looking Information & 34 & $87.20 \%$ & 45 & $46.88 \%$ & 13 & $34.21 \%$ \\
Figures \& Graphs & 22 & $56.40 \%$ & 21 & $21.88 \%$ & 9 & $23.68 \%$ \\
General Financial Information & 36 & $92.30 \%$ & 49 & $51.04 \%$ & 28 & $73.68 \%$ \\
IFR & 36 & $92.30 \%$ & 51 & $53.13 \%$ & 33 & $86.84 \%$ \\
Current Annual Report & 35 & $89.70 \%$ & 48 & $50 \%$ & 33 & $86.84 \%$ \\
\hline
\end{tabular}

* Based on a total number of 39 companies with websites in Qatar

** Based on a total number of 96 companies with websites in Oman

*** Based on a total number of 38 companies with websites in Bahrain

Table 11. Internet Disclosure Statistics by Country

\subsection{Hypotheses Testing}

Kruskal-Wallis test is used to test the first hypothesis. For testing the remaining five hypotheses $\left(\mathrm{H}_{2}-\mathrm{H}_{6}\right)$, logistic regression is used to examine the determinants of IFR in the GCC countries.

Table 12 reveals that there are significant differences at $1 \%$ level between the corporate Internet disclosure among the three GCC countries in terms of investor relations $\left(\mathrm{Chi}^{2}=53.544\right)$, corporate governance report $\left(\mathrm{Chi}^{2}=54.207\right)$, multimedia content $\left(\mathrm{Chi}^{2}=15.315\right)$, forward looking information $\left(\mathrm{Chi}^{2}=30.705\right)$, the use of figures and graphs $\left(\mathrm{Chi}^{2}=21.432\right)$, general financial information $\left(\mathrm{Chi}^{2}\right.$ 
$=31.111)$, Internet financial reporting $\left(\mathrm{Chi}^{2}=35.965\right)$, and the disclosure of current annual report $\left(\mathrm{Chi}^{2}=37.193\right)$. These results support the first hypothesis that there is a significant difference in the attributes of corporate Internet disclosure among the three GCC countries. Meanwhile, firms in the three countries have similar disclosure patterns when it comes to general company information, product and services information and having an email link on their websites as shown in table 12 .

\begin{tabular}{lccccc}
\hline \multirow{2}{*}{ Disclosure Attribute } & \multicolumn{3}{c}{ Mean Rank } & \multicolumn{2}{c}{ Kruskal-Wallis } \\
\cline { 2 - 6 } & Qatar & Oman & Bahrain & Chi-Square & Sig. \\
& & & & & \\
\hline Investor Relation & 139.31 & 78.29 & 106.20 & 53.544 & 0.000 \\
CG Report & 134.04 & 79.30 & 108.50 & 54.207 & 0.000 \\
Email Link & 98.58 & 96.70 & 93.90 & 0.708 & 0.702 \\
Multimedia & 110.58 & 87.46 & 108.30 & 15.315 & 0.000 \\
Company Information & 103.54 & 93.26 & 98.80 & 4.034 & 0.133 \\
Products \& Services Information & 105.54 & 95.26 & 91.20 & 4.591 & 0.101 \\
Forward Looking Information & 134.19 & 88.73 & 81.70 & 30.705 & 0.000 \\
Figures \& Graphs & 124.65 & 88.34 & 92.10 & 21.432 & 0.000 \\
General Financial Information & 128.62 & 81.63 & 107.20 & 31.111 & 0.000 \\
IFR & 125.12 & 79.83 & 115.70 & 35.965 & 0.000 \\
Current Annual Report & 124.65 & 79.28 & 117.70 & 37.193 & 0.000 \\
\hline
\end{tabular}

Table 12. Kruskal-Wallis Test Results

The following equation is used to test hypotheses two to six:

$$
\text { IFR }=\alpha+\beta_{1} \text { ROA }+\beta_{2} \text { AudTyp }+\beta_{3} \text { IndTyp }+\beta_{4} L v g+\beta_{5} \text { FrmSize }+\varepsilon
$$

Using logistic regression model to examine the determinants of IFR in the GCC countries (QE, MSM, and BB), as in the equations above. Where, $\mathrm{Chi}^{2}=$ $31.176, \mathrm{p}=0.000$, Cox and snell $\mathrm{R}^{2}=0.150$, and -2 Log likelihood $=222.865$. The results in Table 13 show that the only factor that significantly impacts Internet financial reporting in the GCC countries is firm size, where wald $=9.075$ $(p$-value $=0.003)$ at $1 \%$ level. All other variables show insignificant effect on Internet financial reporting in the three countries. The results are consistent with the findings of previous studies (Ashbaugh et al., 1999; Craven and Marston, 1999; Pirchegger and Wagenhofer, 1999; Debreceny et al., 2002; Ettredge et al., 2002; Oyelere et al., 2003; Fisher et al., 2004; Chan and Wickramasinghe, 2006; 
Trabelsi, 2007; Ezat and El-Masry, 2008; del Carmen Briano Turrent and Ariza, 2012).

The results can be justified by the fact that to reduce these agency costs, larger firms disclose a large flow of corporate information (Jensen and Meckling, 1976). Also, large companies are more likely to use information technology than small ones to improve financial reporting to meet the greater demand for information (Xiao et al., 1996). The relative cost of disclosing information may also be lower than smaller ones (Oyelere et al., 2003). Furthermore, according to the political cost hypothesis it is argued that larger firms face more demands for information from analysts than smaller firms (McKinnon and Dalimunthe, 1993; Boubaker et al., 2012).

\begin{tabular}{lcccc}
\hline \multirow{2}{*}{ Variables } & \multicolumn{3}{c}{ Dependent Variable (IFR) } \\
\cline { 2 - 5 } Constant & Coefficient & SE & Wald & $p$-value \\
ROA & -6.824 & 1.934 & $12.455^{*}$ & 0.000 \\
AudTyp & 0.977 & 2.149 & 0.207 & 0.649 \\
IndTyp & 0.477 & 0.401 & 1.416 & 0.234 \\
Lvg & 0.325 & 0.242 & 1.796 & 0.180 \\
FrmSize & 0.454 & 0.611 & 0.552 & 0.457 \\
& 0.303 & 0.101 & $9.075^{*}$ & 0.003 \\
-2 Log likelihood & 222.865 & & & \\
Cox and Snell R2 & 0.150 & & & \\
Chi-square & 31.176 & & & \\
$n$ & 192 & & & \\
$* 0.01$ level & & &
\end{tabular}

Table 13. Logistic Regression Results

\section{SUMMARY AND CONCLUSION}

Emerging globalization, new economic challenges, rapid increase of information technologies have all increased the value of reliable information in capital markets. Traditional financial reporting may no longer be capable of capturing the economic implications of many of these changes in a timely manner. The Internet however can provide a valuable means to disseminate financial information a timely and less costly way. The benefits to be derived from Internet financial reporting in the modern era of globalisation and endemic market inter-linkages are likely to far outweigh the pecuniary costs. Moreover, IFR provides companies with the opportunity to make information available to interested parties on a 
timely basis and substantially reduce the costs associated with traditional paperbased financial reports. This is of significant importance in a time where a company's stakeholders are widely dispersed due to globalisation. The importance of the Internet in disseminating in a more timely and efficient manner is recognised by the OECD in its Principles of Corporate Governance.

There is little empirical study on IFR practices in the Middle East region. This paper is an important contribution to filling the gap in the literature as it provides insights into IFR in the Middle East that will benefit all stakeholders with an interest in corporate reporting. The objective of this paper is to examine Internet financial reporting practices and determinants in companies listed in Qatar Stock Exchange (Qatar), Muscat Securities Market (Oman), and Bahrain Bourse (Bahrain).

Data has been collected and analysed on 192 companies listed in the stock markets in Qatar, Oman and Bahrain. Only 173 (90\%) of these companies maintain websites, and $120(63 \%)$ provide Internet financial reporting on their websites. Most of these companies use the PDF format to publish financial information and some companies use the Internet to provide additional financial information, in the form of financial highlights. The results also reveal that most companies use conventional web presentation, mainly text to present financial information. They only take advantage of multimedia mainly in disclosing information related to product and services. Companies do not utilize the potential of computer technologies in adding value to financial disclosure. The type of disclosure also varies substantially among companies with some providing full sets of their annual reports, while others only provide condensed financial statements. There is variance also in the timeliness of disclosure, while the majority of firms provide timely data $(67 \%)$, others provide outdated financial information.

Overall, the results reveal a good use of the Internet for financial reporting purposes in Qatar Oman and Bahrain. However, the results show that large firms tend to disclose more information in order to reduce information asymmetry and also reduce agency costs. Also, the more exposure large firms are subjected to leads to the firms being under higher pressure to disclose information. Large corporations seem to disclose information on the internet due to the fact they can benefit from the lower cost that results from these firms having the resources to do 
so. Additionally, the results are consistent with agency theory that large firms attempt to reduce the high agency costs associated with information asymmetry between market participants by disclosing a large flow of corporate information. Furthermore, according to the political cost hypothesis, large firms attract more financial analysts putting firms under higher pressure because they are more publicly visible.

The results reveal that there are significant differences in most of the characteristics of corporate internet disclosure among the three GCC countries; these are: investor relation, corporate governance reports, multimedia content, forward looking information, use of figures and graphs, general financial information, internet financial reporting and the disclosure of current annual reports on companies' websites. It appears that Qatar is outperforming both Oman and Bahrain in the disclosure of the various characteristics. Though the current level of technological expertise and development in Oman and Bahrain is more than adequate for the creation, operation and maintenance of corporate internet disclosure, there is a limited use of the internet for disclosure of certain information in these two countries. It appears that, despite the growing use of the internet as a medium for the dissemination of corporate information in other regions and countries of the world, many companies in these two countries either do not use their website to disseminate such information. It is possible, that listed companies in both countries do not see an incremental benefit in engaging in IFR, given that the financial information of most of them is already published through the websites of the MSM and the BB. However, this should not be the case, as companies should endeavour to take control and responsibility for the information communicated to their stakeholders. However, there are no significant differences when it comes to the disclosure of general company and product \& service information, and the provision of an Email link.

GCC countries are likely to witness an upsurge in IFR over the next few years and regulators and other governmental agencies, as well as other stakeholder groups will need to be prepared for this imminent development. There is little by way of regulatory guidance or pronouncement on IFR in Qatar, Oman and Bahrain and perhaps in all countries of the GCC. This situation needs to be remedied and regulations need to streamline IFR practices to avoid the problem of 
excessive variety of non-standardized practices currently used. Regulatory guidance may also cover issues such as whether IFR is a direct substitute or complement for hard copy financial statements that companies are required by law to provide; rules regarding the publication of audited and non-audited financial information on the internet.

\section{REFERENCES}

ABD EL SALAM, O. (1999): "The introduction and application of international accounting standards to accounting disclosure regulations of a capital market in developing country: the case of Egypt", PhD thesis, Heriot-Watt University, Edinburgh.

ALMILIA, S.; SURABAYA, S. (2009): "Determining factors of Internet financial reporting in Indonesia", Accounting and Taxation, vol. 1, n. 1: 87-99.

ALY, D.; SIMAON, J.; HUSSAINEY, K. (2009): "Determinants of CIR: evidence from Egypt", Managerial Auditing Journal, vol. 25, n. 2: 182-202. http://dx.doi.org/10.1108/02686901011008972

AHMED, K.; NICHOLLS, D. (1994): "The impact of non-financial company characteristics on mandatory disclosure compliance in developing countries: the case of Bangladesh", The International Journal of Accounting, vol. 29: 62-77.

ALLAM, A.; LYMER, A. (2002): "Benchmarking Financial Reporting Online: The 2001 Review", Working Paper, University of Birmingham, Birmingham, UK.

ASHBAUGH, H.; JOHNSTONE, K.; WARFIELD, T. (1999): "Corporate Reporting on the Internet", Accounting Horizons, vol. 13, n. 3: 241257.http://dx.doi.org/10.2308/acch.1999.13.3.241

BAKER, C.; WALLAGE, P. (2000): "The Future Of Financial Reporting in Europe: Its Role in Corporate Governance", The International Journal of Accounting, vol. 35, n. 2: 173-187.http://dx.doi.org/10.1016/S00207063(00)00044-3

BOLLEN, L.; HASSINK, H.; BOZIC, G. (2006): "Measuring and explaining the quality of Internet investor relations activities: a multinational empirical analysis", 
International Journal of Accounting Information Systems, vol. 7: 273-98. http://dx.doi.org/10.1016/j.accinf.2006.04.005

BONSÓN, E.; ESCOBAR, T. (2002): "A survey on voluntary disclosure on the Internet: empirical evidence from 300 European Union companies", The International Journal of Digital Accounting Research, vol. 2, n. 1: 27-51. http://www.uhu.es/ijdar/10.4192/1577-8517-v2_2.pdf

BORITZ, J.; NO, W. (2005): "Security in XML-Based Financial Reporting Services on the Internet", Journal of Accounting and Public Policy, vol. 24, n. 1: 11-35. http://dx.doi.org/10.1016/j.jaccpubpol.2004.12.002

BOUBAKER, S.; LAKHAL, F.; NEKHILI, M. (2012): "The Determinants of Web-Based Corporate Reporting in France", Managerial Auditing Journal, vol. 27, n. 2: 126-155. http://dx.doi.org/10.1108/02686901211189835

BRENNAN, N.; HOURIGAN, D. (1998): "Corporate reporting on the Internet by Irish companies", Accountancy Ireland, vol. 30, n. 6: 18-21.

CHAN, W.K.; WICKRAMASINGHE, N. (2006): "Using the Internet For Financial Disclosures: The Australian Experience", International Journal of Electronic Finance, vol. 1, n. 1: 118-150.

CRAVEN, B.; MARSTON, C. (1999): "Financial Reporting on the Internet by Leading UK Companies", The European Accounting Review, vol. 8, n. 2: 321333. http://dx.doi.org/10.1080/096381899336069

DEANGELO, L. (1981): "Auditor size and audit quality", Journal of Accounting and Economics, vol. 3, n. 3: 183-199. http://dx.doi.org/10.1016/0165$\underline{4101(81) 90002-1}$

DEBRECENY, R.; GRAY, G.; RAHMAN, A. (2002): "The determinants of Internet Financial Reporting", Journal of Accounting and Public Policy, vol. 21, n. $(4 / 5): 371-394$.

DEBRECENY, R.; RAHMAN, A. (2005): "Firm-specific determinants of continuous corporate disclosure", The International Journal of Accounting, vol. 40: 249-78. http://dx.doi.org/10.1016/j.intacc.2005.06.001 
DEL CARMEN BRIANO TURRENT, G.; ARIZA, L. (2012): "Corporate information transparency on the Internet by listed companies in Spain (IBEX35) and Mexico (IPYC)", The International Journal of Digital Accounting Research, vol. 12: 1-37.http://www.uhu.es/ijdar/10.4192/1577-8517-v12_1.pdf

DELLER, D.; STUBENRATH, M.; WEBER, C. (1999): "A Survey on the Use of the Internet for Investor Relations in the USA, The UK and Germany", The European Accounting Review, vol. 8, n. 2: 351-364.http://dx.doi.org/10.1080/09 $\underline{6381899336087}$

ETTREDGE, M.; RICHARDSON, V.; SCHOLZ, S. (2001): "The Presentation of Financial Information at Corporate Websites", International Journal of Accounting Information Systems, vol. 2: 149-168. http://dx.doi.org/10.1016/S1467 $\underline{-0895(00) 00017-8}$

ETTREDGE, M.; RICHARDSON, V.; SCHOLZ, S. (2002): "Dissemination of Information for Investors at Corporate Websites", Journal of Accounting and Public Policy, vol. 21, n. (4/5): 357-369.

EZZAT, A.; EL-MASRY, A. (2008): "The Impact of Corporate Governance on the Timeliness of Corporate Internet Reporting by Egyptian Listed Companies", Managerial Finance, vol. 34, n. 12:.848-867.

FASB (2000): Electronic Distribution of Business Reporting Information. Steering Committee Report Series. http://www.fasb.org

FISHER, R.; OYELERE, P.; LASWAD, F. (2004): "Corporate Reporting On The Internet: Audit Issues And Content Analysis Of Practices", Managerial Auditing Journal, vol. 19, n. 3: 412-139. http://dx.doi.org/10.1108/02686900410524418

GARCÍA-BORBOLLA, A.; LARRÁN, M.; LÓPEZ, R. (2005): "Empirical evidence concerning SMEs' corporate websites: Explaining factors, strategies and reporting", The International Journal of Digital Accounting Research, vol. 5: 171202. http://www.uhu.es/ijdar/10.4192/1577-8517-v5_5.pdf

GOWTHORPE, C.; AMAT, O. (1999): "External Reporting of Accounting and Financial Information via the Internet in Spain", The European Accounting Review, vol. 8 n. 2: 365-371. http://dx.doi.org/10.1080/096381899336096 
GOWTHORPE, C.; FLYNN, G. (2001): Smaller Listed Companies' Financial Reporting on the Internet 2000/2001. Institute of Chartered Accountants in England and Wales, London, UK.

GOWTHORPE, C. (2004): "Asymmetrical Dialogue? Corporate Financial Reporting via the Internet", Corporate Communication: An International Journal, vol. 9, n. 4: 283-293. http://dx.doi.org/10.1108/13563280410564020

GREEN, G.; SPAUL, B. (1997): "Digital accountability", Accountancy, International Edition, May: 49-50.

HAIL, L. (2002): "The impact of voluntary corporate disclosures on the ex ante cost of capital for Swiss firms", European Accounting Review, vol. 11, n. 11: 74173. http://dx.doi.org/10.1080/0963818022000001109

HANIFFA, R.; COOKE, T. (2005): "The impact of culture and governance on corporate social reporting", Journal of Accounting and Public Policy, vol. 24, n. 5: 391-430. http://dx.doi.org/10.1016/j.jaccpubpol.2005.06.001

HEALY, P.; PALEPU, K. (2001): "Information asymmetry, corporate disclosure, and the capital markets: a review of the empirical disclosure literature", Journal of Accounting and Economics, vol. 31: 405-40.http://dx.doi.org/10.1016/S0165$\underline{4101(01) 00018-0}$

HEDLIN, P. (1999): "The Internet as a Vehicle for Investor Relations: The Swedish Case", The European Accounting Review, vol. 8; n. 2: 373-381. http://dx.doi.org/10.1080/096381899336104

HODGE, F. (2001): "Hyperlinking Unaudited Information to Audited Financial Statements: Effects on Investor Judgements", The Accounting Review, vol. 76; $\mathrm{n}$. 4: 675-691. http://dx.doi.org/10.2308/accr.2001.76.4.675

HOSSAIN, M.; PERERA, M. RAHMAN, A.R. (1995): "Voluntary disclosure in the annual reports of New Zealand companies", Journal of International Financial Management \& Accounting, vol. 6, n. 1: 69-87. http://dx.doi.org/10.1111/j.1467-646X.1995.tb00050.x 
HUSSAIN, M.; ISLAM, M.; GUNASEKARAN, A.; MASKOOKI, K. (2002): "Accounting Standards and Practices of Financial Institutions in GCC Countries", Managerial Auditing Journal, vol. 17, n. 7: 350-362. http://dx.doi.org/10.1108/02 $\underline{686900210437453}$

HUSSAIN, S.; MALLIN, C. (2002): "Corporate Governance in Bahrain", Corporate Governance: An International Review, vol. 10, n. 3: 197-210. http://dx.doi.org/10.1111/1467-8683.00284

ISMAIL, T.H. (2002): An Empirical Investigation of Factors Influencing Voluntary Disclosure of Financial Information on the Internet in the GCC Countries. http://ssrn.com/abstract $=420700$

ISMAIL, T.; SOBHY, N. (2009): "Determinants of Auditors' Perceptions of the Work Needed in the Audit of Internet-Based Financial Reports in Egypt", Journal of Applied Accounting Research, vol. 10, n. 2: 132-150.http://dx.doi.org/10.110 $\underline{8 / 09675420910984691}$

JENSEN, M.; MECKLING, W. (1976): "Theory of the Firm: Managerial Behavior, Agency Costs and Ownership Structure", Journal of Financial Economics, vol. 3 n. 4: 305-360. http://dx.doi.org/10.1016/0304-405X(76)90026-X

JONES, M.; XIAO, J. (2004): "Financial Reporting on The Internet by 2010: A Consensus View", Accounting Forum, vol. 24: 237-263. http://dx.doi.org/10.1016 /j.accfor.2004.07.002

JOSHI, P.; WAKIL, A. (2004): "A Study of The Audit Committees' Functioning in Bahrain: Empirical Findings", Managerial Auditing Journal, vol. 19, n. 7, 832858. http://dx.doi.org/10.1108/02686900410549394

KHADAROO, I. (2005): "Corporate reporting on the Internet: Some Implications for The Auditing Profession", Managerial Auditing Journal, vol. 20; n. 6: 578591. http://dx.doi.org/10.1108/02686900510606074

LAI, S.; LIN, C.; LI, H.; WU, F. (2010): "An empirical study of the impact of Internet financial reporting on stock prices", The International Journal of Digital Accounting Research, vol. 10: 1-26. http://dx.doi.org/10.4192/1577-8517-v10_1

LARRAN, M.; GINER, B. (2002): "The use of the Internet for corporate reporting by Spanish companies", The International Journal of Digital Accounting Research, vol. 2, n. 3: 53-82. http://dx.doi.org/10.4192/1577-8517-v2_3 
LASWAD, F.; OYELERE, P.; FISHER, R. (2000): "Internet Financial Reporting, Opportunities and Challenges", African Finance Journal, vol. 2; n. 2: 40-46.

LASWAD, F.; FISHER, R.; OYELERE, P. (2005): "Determinants of Voluntary Internet Financial Reporting by Local Government Authorities", Journal of Accounting and Public Policy, vol. 24: 101-121. http://dx.doi.org/10.1016/j.jaccp ubpol.2004.12.006

LEFTWICH, R. (1981): "Evidence of the impact of mandatory changes in accounting principles on corporate loan agreements": Journal of Accounting and Economics. March: 3-36. http://dx.doi.org/10.1016/S0165-4101(81)80001-8

LOUWERS, T.; PASEWARK, W.; TYPPO, E. (1996): "Silicon Valley Meets Norwalk", Journal of Accountancy, N.186: 20-24.

LYMER, A. (1999), "The Internet and the future of corporate reporting in Europe", The European Accounting Review, Vol. 8 N. 2, pp. 289-301. http://dx.doi.org/10.1080/096381899336041

LYMER, A.; DEBRECENY, R.; GRAY, G.; RAHMAN, A. (1999): Business Reporting on the Internet. International Accounting Standards Committee, London.

LYMER, A.; DEBRECENY, R. (2003): "The Auditor and Corporate Reporting on the Internet: Challenges and Institutional Responses", International Journal of Auditing, vol. 7, n. 2:103-120. http://dx.doi.org/10.1111/1099-1123.00063

MALONE, D.; FRIES, C.; JONES, T. (1993): "An empirical investigation of the extent of corporate financial disclosure in the oil and gas industry", Journal of Accounting, Auditing and Finance, vol. 8: 249-273.

MARSTON, C. (2003): "Financial Reporting on the Internet by Leading Japanese Companies", Corporate Communication: An International Journal, vol. 8, n. 1: 23-34. http://dx.doi.org/10.1108/13563280310458894

MARSTON, C.; POLEI, A. (2004): "Corporate Reporting on the Internet by German Companies", International Journal of Accounting Information Systems, vol. 5: 285-311. http://dx.doi.org/10.1016/j.accinf.2004.02.009 
MCCAFFERTY, J. (1995): "Investor Relations: How Much to Reveal Online", CFO, December: 12 .

MCKINNON, J.; DALIMUNTHE, L. (1993): "Voluntary Disclosure of Segment Information By Australian Diversified Companies", Accounting \& Finance, vol. 33, n. 1: 33-50. http://dx.doi.org/10.1111/j.1467-629X.1993.tb00192.x

MEEK, G.; ROBERTS, C.; GRAY, S. (1995): "Factors influencing voluntary annual report disclosure by U.S, U.K and Continental European multinational corporations", Journal of International Business Studies, vol. 26, n. 3: 555-572. http://dx.doi.org/10.1057/palgrave.jibs.8490186

MITCHELL, J.; CHIA, C.; LOH, A. (1995): "Voluntary disclosure of segment information: Further Australian evidence", Accounting \& Finance, vol. 35, n. 2: 116. http://dx.doi.org/10.1111/j.1467-629X.1995.tb00283.x

MOHAMED, E. (2010): "Internet Financial Reporting (IFR) in the GCC: Extent and Practices", International Journal of Accounting and Finance, vol. 2, n. 1: 113129. http://dx.doi.org/10.1504/IJAF.2010.031914

MOMANY, M.; AL-SHORMAN, S. (2006): "Web-based voluntary financial reporting of Jordanian companies", International Review of Business Research Papers, vol. 2: 127-39.

OYELERE, P.; KURUPPU, N. (2012): "Voluntary Internet Financial Reporting Practices of Listed Companies in the United Arab Emirates", Journal of Applied Accounting Research, vol. 13, n. 3: 298-315. http://dx.doi.org/10.1108/09675421 $\underline{21281353}$

OYELERE, P.; LASWAD, F.; FISHER, R. (2003): "Determinants of Internet Financial Reporting by New Zealand Companies", Journal of International Financial Management and Accounting, vol. 14, n. 1: 26-63. http://dx.doi.org/10 $.1111 / 1467-646$ X.00089

PIRCHEGGER, B.; WAGENHOFER, A. (1999): "Financial Information on the Internet: A Survey of the Homepages of Austrian Companies", The European Accounting Review, vol. 8, n. 2: 383-395. http://dx.doi.org/10.1080/0963818993 $\underline{36113}$

RAFFOURNIER, B. (1995): "The determinants of voluntary financial disclosure by Swiss listed companies", European Accounting Review, vol. 4, n. 2: 261-80. 


\section{http://dx.doi.org/10.1080/09638189500000016}

RAVLIC, T. (2000): "Wild Wild Web", Australian CPA, August: 26-30.

SALAWU, R.O. (2009): "Financial reporting on the Internet by quoted companies in Nigeria", Proceedings of the 10th Annual Conference of Repositioning African Business and Development for the 21st Century. Retrieved on 15th of March 2013 from http://www.iaabd.org/2009_iaabd_proceedings/track1a.pdf

SEC (2002): Final Rule: Acceleration of Periodic Report Filing Dates and Disclosure Concerning Website Access to Reports. Securities and Exchange Commission. www.sec.gov

SEC (2003a): Final Rule: Disclosure Required by Sections 406 and 407 of the Sarbanes-Oxley Act of 2002. Securities and Exchange Commission. www.sec.gov SEC (2003b): Final Rule: Mandated Electronic Filing and Website Posting for Form 3,4 and 5. Securities and Exchange Commission. www.sec.gov

SINGHVI, S.; DESAI, H. (1971): "An empirical analysis of the quality of corporate financial disclosure", Accounting Review, vol. 46, n. 1: 129-38.

SMITH, B.; PEPPARD, D. (2005): "Internet Financial Reporting: Benchmarking Irish Plcs against Best Practice", Accountancy Ireland, vol. 37, n. 6: 22-24.

TRABELSI, S. (2007): "An Empirical Examination of Corporate Website as a Voluntary Disclosure Medium", paper presented at the BAA Annual Conference, Royal Holloway, University of London, London, UK.

TRABELSI, S.; LABELLE, R. (2006): "Evidence that corporate websites is a part of the firm's overall disclosure package", working paper, Brock University, St Catherines. http://accounting.uwaterloo.ca/seminars/old_papers/

TRITES, G. (1999): The Impact of Technology on Financial and Business Reporting. Canadian Institute of Chartered Accountants, Canada

TRITES, G.; SHEEHY, D. (1997): "Electronic Disclosure Making a Hit on the Net", CA Magazine, March: 10.

WAGENHOFER, A. (2003): "Economic Consequences of Internet Financial Reporting", Schmalenbach Business Review, vol. 55, October: 262-279. 
WALLACE, R.; NASER, K.; MORA, A. (1994): "The relationship between the comprehensiveness of corporate annual reports and firm characteristics in Spain", Accounting \& Business Research, vol. 25, n. 97: 41-53.

WALLMAN, S. (1997): "The Future of Accounting and Financial Reporting, Part 5: Access Accounting", Accounting Horizon, vol. 11, n. 2: 103-116.

WICKRAMASINGHE, N. (2006): "Knowledge Creation: A Meta-Framework", International Journal of Innovation and Learning, vol. 3, n. 5: 558-573.

WICKRAMASINGHE, N.; LICHTENSTEIN, S. (2006): "Supporting Knowledge Creation with E-mail", International Journal of Innovation and Learning, vol. 3 no. 4: 416-426.

XIAO, J.; DYSON, R.; POWELL, P. (1996): "The Impact of Information Technology on Corporate Financial Reporting: A Contingency Perspective", British Accounting Review, vol. 28, n. 3: 203-27. http://dx.doi.org/10.1006/bar e.1996.0015

XIAO, J.; YANG, H.; CHOW, C. (2004): "The Determinants and Characteristics of Voluntary Internet-Based Disclosures by Listed Chinese Companies", Journal of Accounting and Public Policy, vol. 23, n. 3: 191-225. http://dx.doi.org/10.1016/ j.jaccpubpol.2004.04.002 


\section{Appendix A: Summary of Key Studies on Internet Financial Reporting}

\begin{tabular}{lcl}
\multicolumn{1}{c}{ Author(s) } & Country & \multicolumn{1}{c}{ Key Issues/Findings } \\
\hline Bonson and & Europe & $\begin{array}{l}\text { Analyzes the information provided on the Internet by leading companies in } \\
\text { different European countries. The paper uses statistical tests to determine the } \\
\text { Escobar (2002) }\end{array}$ \\
& $\begin{array}{l}\text { relationships between transparency (dependent variable) and companies' sector, } \\
\text { country of origin and size (independent variables). The results suggest that there is } \\
\text { a statistically significant relationship between these three variables and the extent } \\
\text { of voluntary disclosure (transparency) on the Internet. }\end{array}$
\end{tabular}

Craven and

Marston (1999)

Chan and

Wickramasinghe

(2006)

Debreceny, et al. (2002)

del Carmen Briano Turrent and Ariza, (2012)

Delleret al. (1999)

Ettredge et al.

(2001)

Fisher et al. (2004)

Gowthorpe and

Amat (1999)

Hedlin (1999)
UK

Examine the extent of IFR practices by UK companies. Find size to be a major determinant of the use and extent of IFR, but do not find the same relationship for industry type.

Australia

Empirical results from Australia show that accounting firm size plays a significant role in explaining the IFD quality. However, the PA firm quality is not important for the adoption of IFD. This has far reaching implications for using the internet as a tool for financial disclosures.

International

Study of IFR practices of 660 large companies in 22Countries and find disclosure environment to be an important environmental driver for IFR presentation and content. Also find presentation of IFR to be more associated with certain identified determinants than the content of IFR.

Spain and Mexico

Provide a comparative study of the corporate transparency of listed companies from Mexico and Spain by creating an index of corporate transparency on the Internet (e-CTI) and identified the factors that affect this index using multiple regression analysis. The results show significant differences in the level of information disclosure between the two countries. They also reveal that the factors most telling with regards to corporate transparency ate the strength and application of law, GDP per capita, inflation and firm-level variables such as ownership concentration and Chairman of the Board-Chief Executive Officer (COB-CEO) duality.

US, UK and Compare the IFR activities of US, UK and German companies and find IFR to be Germany more common in the USA. Also find that although Internet technology offers a variety of possibilities for communication with investors, only a fraction of the possibilities is used in all three countries.

US Evaluation and comparison of IFR practices of US companies and find several practices of potential concern for the accounting profession.

New

Zealand

The exploratory study identifies the key audit implications of IFR and analysed the contents of all listed company Websites in New Zealand. The results of their content analysis of auditor Web-related practices reveal several significant concerns for the auditing profession with respect to the presentation, context, and content of the audit report in a Web-based environment.

Spain

Report IFR practices of Spanish companies quoted on the Madrid Stock Exchange, placing IFR in context by reporting extent of Internet access and the actual and potential development of the Internet as a means of establishing corporate dialogue with stakeholders.

Sweden Reports the results of a survey of 60 companies listed on the Stockholm Stock Exchange and finds larger companies to be more advanced in their use of IFR as a tool for communication with corporate investors. 
Ismail and Sobhy Egypt (2009)

Jones and Xiao (2004)

Khadaroo (2005)

Lai et al. (2010)

Laswadet al. (2005)

Lymer (1999)

Lymer and

Debreceny (2003)

Marston (2003)

Marston and Polei (2004)

Mohamed (2010)

Oyelereet al. (2003)

New
Constitute and test a framework of factors that might affect auditors' perceptions of the work needed to audit internet-based financial reports. Empirical results provid evidence of a significant association between auditors' perceptions of the work needed to audit IBFR and auditors' knowledge of inherent risks of internet reporting, quality systems, audit tenure, legal form of client, client industry group, user needs of financial information, and legislation environment.

UK Delphi study of corporate financial reporting by 2010 find that financial reporting would evolve into a core of general purpose, standardized information in both the hard copy and Internet versions, together with a non-core of general purpose and customized information, and that radical changes such as real-time reporting and disclosureof raw data will not occur. IFR will need to be either standardized or customized.

Malaysia Examines IFR practices of Malaysian companies, with emphasis on auditing implications. Finds increasein quantity, but little improvement in quality of internet reporting information to users. Highlightes the issue of auditors having little control over web contents and changes that could be made to audited information.

Taiwan Examine the economic consequences of IFR in Taiwan. The results show that the stock prices of IFR firms change more quickly than those of the non-IFR, the cumulative abnormal returns of the firms with IFRare significantly higher than those of the firms without IFR. The results also indicate that firmswith a higher degree of information transparency yield a higher abnormal return on their stockprices.

Zealand

Examine the voluntary Internet financial reporting practices of local authorities and find leverage, municipal wealth, press visibility, and type of council to be associated with the Internet financial reporting practices of local authorities in New Zealand.

Europe Provides a detailed literature review of both academic and professional material produced on IFR and outlines a wide range of issues that need to be considered by companies, accounting regulators and standard setters in determining how this form of reporting should develop in the future.

International Review the state of guidance provided on IFR by regulators and standardsetters.Find that despite a clear recognition of the challenges posed by IFR, actual enactments fall far short of requirements.

Japan Survey the Internet reporting practices of top Japanese companies in 1998 and 2001, and found that the majority of these companies (about 79\%) had a website in English, with about $69 \%$ reporting some financial information on their website in 1998. Finds size to be the main determinant of the existence of a corporate website.

Germany

Examine the IFR practices of German companies between 2000 and 2003 and find significant improvements in the quantity and presentation of financial information at corporate Websites. They also find firm size to be the only explanatory factor for the quantity of information disclosed for both periods. Foreign listing status was found to be a significant explanatory in 2003, while free float was significant for 2000 .

GCC Investigates the extent and variety of practices of IFR by companies listed on the Muscat Securities Market (MSM) in Oman and the Bahrain Stock Exchange (BSE) in Bahrain. The results indicate that IFR is still at an embryonic stage in Oman and Bahrain.

Examine the determinants of voluntary IFR practices by New Zealand companies and find that some determinants of traditional financial reporting such as size, liquidity, industrial sector and spread of shareholding are also determinants of voluntary adoption of IFR. However, other firm characteristics, such as leverage, profitability and internationalization, do not explain IFR practices. 
Oyelere and

Kuruppu (2012)

Pirchegger and

Wagenhofer (1999)

Xiao et al. (2004)
UAE Investigate the use of the internet as a channel forvoluntary communication of financial information by companies listed on two stock exchanges in theUnited Arab Emirates. The paper focuses on the extent and variety of IFR by these companies. The results show that about 87 percent of UAE-listed companies operate websites, and only 88 of these companies (about 67 percent) use their websites to communicate financial information.

Austria and Analyze the IFR practices of Austrian companies and compared them to those of Germany German listed companies. Find that larger Austrian companies and those with higher free float percentage scored higher on measures of IFR disclosure.

China Analyze the determinants of Chinese listed companies' voluntary IFR practices and find that the companies IFR disclosure choices are responsive to specific attributes of their environment. 